\section{OAK RIDGE \\ $Y-12$ \\ PLANT}

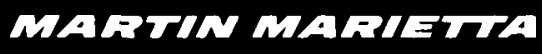

CLAD VENT SET CUP OPEN END (CLOSURE WELD ZONE) WALL-THICKNESS STUDY

G. B. Ulrich

Materials Engineering Department Development Division

M. W. Sherrill

Quality Division

September 1994 


\title{
CLAD VENT SET CUP OPEN END (CLOSURE WELD ZONE) \\ WALL-THICKNESS STUDY
}

\author{
G. B. Ulrich \\ Materials Engineering Department \\ Development Division
}

M. W. Sherrill

Quality Division

\author{
Prepared by the \\ Oak Ridge Y-12 Plant \\ P.O. Box 2009, Oak Ridge, Tennessee 37831-8169 \\ managed by \\ MARTIN MARIETTA ENERGY SYSTEMS, INC. \\ for the \\ U.S. DEPARTMENT OF ENERGY \\ under contract DE-AC05-84OR21400
}




\section{DISCLAIMER}

This report was prepared as an account of work sponsored by an agency of the United States Government. Neither the United States Government nor any agency thereof, nor any of their employees, make any warranty, express or implied, or assumes any legal liability or responsibility for the accuracy, completeness, or usefulness of any information, apparatus, product, or process disclosed, or represents that its use would not infringe privately owned rights. Reference herein to any specific commercial product, process, or service by trade name, trademark, manufacturer, or otherwise does not necessarily constitute or imply its endorsement, recommendation, or favoring by the United States Government or any agency thereof. The views and opinions of authors expressed herein do not necessarily state or reflect those of the United States Government or any agency thereof. 


\section{DISCLAIMER}

Portions of this document may be illegible in electronic image products. Images are produced from the best available original document. 


\section{CONTENTS}

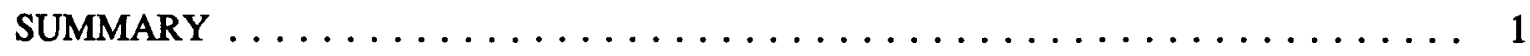

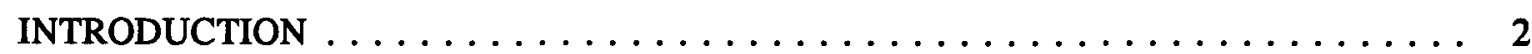

PROCEDURE $\ldots \ldots \ldots \ldots \ldots \ldots \ldots \ldots \ldots \ldots \ldots \ldots \ldots \ldots \ldots \ldots \ldots$

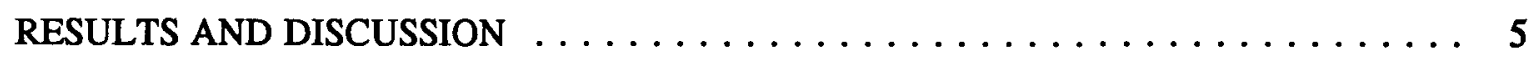

CONCLUSION AND FUTURE WORK $\ldots \ldots \ldots \ldots \ldots \ldots \ldots \ldots$

REFERENCES $\ldots \ldots \ldots \ldots \ldots \ldots \ldots \ldots \ldots \ldots \ldots \ldots \ldots \ldots$ 


\section{SUMMARY}

The wall thickness at the open end of Clad Vent Set (CVS) cups is a very important parameter for maintaining control of the fueled CVS closure weld process. Ideally, the wall thickness in the closure weld zone should be constant. The DOP-26 iridium alloy is very difficult to machine; therefore, key dimensional features are established during the two-draw warm-forming operation. Unfortunately, anisotropy in the forming blanks produces four ears at the open end of each cup. Formation of these ears produces axial and circumferential variations in wall thickness. The cup certification requirement is that the wall thickness in the closure weld zone, defined as the $2.5-\mathrm{mm}$ band at the open end of a cup, measure from 0.63 to $0.73 \mathrm{~mm}$. The wall thickness certification data for the open end of the CVS cups have been statistically evaluated. These data show that the cups recently produced for the Cassini mission have well-controlled open-end wall thicknesses. 


\section{INTRODUCTION}

Matched pairs of Clad Vent Set (CVS) cups are used to encapsulate individual ${ }^{238} \mathrm{PuO}_{2}$ fuel pellets for the U.S. Department of Energy (Radioisotope Power Systems Division) General Purpose Heat Source - Radioisotope Thermoelectric Generator (GPHS-RTG) program. The heat from the radioactive decay of the ${ }^{238} \mathrm{Pu}$ is used to produce electrical power thermoelectrically for deep space missions such as the upcoming National Aeronautical and Space Administration Cassini mission to Saturn and the on-going Galileo and Ulysses missions. An autogenous weld using the tungsten inert gas (TIG) process is used for the closure of a fueled CVS. CVS blanks and cups are now produced by Martin Marietta Energy Systems, Inc. (Energy Systems) while the ${ }^{238} \mathrm{PuO}_{2}$ pellet fabrication and CVS closure weld are performed at the Los Alamos National Laboratory. It is critical that variations in wall thickness at the open end (closure weld zone) of each cup be kept to a minimum to ensure a consistent closure-weld process.

DOP-26 iridium alloy sheetstock is electrical discharge machined (EDM) to $51.80 / 52.35 \mathrm{~mm}$ in diameter. These EDM discs are ground to 0.63/0.68-mm-thick forming blanks. The blanks are dimensionally certified and then cleaned electrolytically in potassium cyanide (KCN). The KCN cleaning operation removes some iridium so that the blanks are typically $0.007 \mathrm{~mm}$ thinner than the blank certification values.

The blanks are sandwiched between two tantalum barrier disks (nominally $0.076 \mathrm{~mm}$ thick by $55.88 \mathrm{~mm}$ diam) which are encapsulated by two mildly contoured type 304L stainless steel waster sheets (nominally $0.85 \mathrm{~mm}$ thick by $61 \mathrm{~mm}$ diam). This "blank assembly" is evacuated and sealed by making an autogenous electron beam weld at the circumferential edge of the waster sheets. A blank assembly is deep drawn (with some ironing) into a cup at $925^{\circ} \mathrm{C}$ using a two-draw operation. Table 1 shows the forming tooling parameters.

The first draw achieves a $30 \%$ reduction from iridium blank diameter to iridium cup inside diameter. A blankholder, which applies approximately $1.5 \mathrm{kN}$ of spring force to minimize wrinkling at the cup open end, is used during the first draw. The second draw is done without a blankholder. A contoured, mild steel cup is pressed onto the punch before each cup is second-formed, establishing the appropriate dimensions for subsequent cup fabrication operations. The mild steel cup is stripped off the punch with each formed blank assembly. The second draw achieves an additional $\sim 20 \%$ reduction in the iridium cup inside diameter. The total reduction from blank diameter to finished inside cup diameter is $\sim 45 \%$.

Earing, in the form of four lobes, occurs during deep drawing because of anisotropy present in the wrought/stress-relieved blanks. ${ }^{1,23}$ Of course, this earing produces variations in cup wall thickness both axially and circumferentially. The wall thickness in the closure weld zone, defined as the $2.5-\mathrm{mm}$ band near the open end, is required to be 0.63 to $0.73 \mathrm{~mm}$. Note: the wall thickness requirement for the remainder of the cup is $0.55 \mathrm{~mm}$ minimum. Cups with areas that are too thick can be handworked to the proper thickness whereas cups with areas that are too thin must be downgraded to nonflight-quality applications. 
Table 1. CVS cup forming parameter comparisons (dimensions are in millimeters)

Forming parameter

Iridium blank

Tantalum barrier disk

Type 304L stainless steel waster sheet

Blank assembly thickness

10-min preheat temperature

First form tooling

Punch

Material

Diameter

Radius

Speed $(\mathrm{mm} / \mathrm{s})$

Preheat temperature

Die

Material

Diameter

Entrant radius/exit angle

Counterbore diameter

Preheat temperature

Blankholder

Lubricant

Punch/die clearance w/grafoil

Clearance-to-thickness ratio

Second form tooling

Punch

Material

Diameter

Radius

Speed $(\mathrm{mm} / \mathrm{s})$

Preheat temperature

Mild steel cup

Height

Outside radius

Outside diameter

Open end wall thickness

Die

Material

Diameter

Entrant angle/exit angle

Preheat temperature

Lubricant

Punch (MS Cup)/die clearance

Clearance-to-thickness ratio
Energy Systems

EG\&G-MAT

$51.80 / 52.35$ round $x \quad 0.63 / 0.68$

thick - vacuum stress relieved

55.88 round $\times 0.076$ thick wrought condition

60.96 round $\times 0.838 / 0.864$ thick with mild contour

\subsection{9}

$925^{\circ} \mathrm{C}$

H-13 tool steel

34.239

8.204

22

$250^{\circ} \mathrm{C}$

H-13 tool steel

$40.132 / 40.178$

$9.652 / 10^{\circ}$

62.433

$250^{\circ} \mathrm{C}$

$45^{\circ}$ angle $-1.5 \mathrm{kN}$

0.254 thick grafoil ${ }^{\mathrm{b}}$

2.693/2.716

$1.08 / 1.09$

H-13 tool steel

24.587

3.099

22

$250^{\circ} \mathrm{C}$

18.816

4.168

26.419

Low-0.770/high-0.782

H-13 tool steel

31.623

$30^{\circ} / 10^{\circ}$

$250^{\circ} \mathrm{C}$

Fiske $604^{\circ}$

2.602

1.05
51.80/52.35 round $x 0.63 / 0.68$ thick vacuum stress relieved

55.88 round $x 0.076$ thick annealed

60.96 round $x \quad 0.889 / 0.914$ thick with slightly different mild contour

2.591

$925^{\circ} \mathrm{C}$

Tool steel

34.214

8.204

10

$250^{\circ} \mathrm{C}$

Ampco 25 bronze

40.386

$9.652 / 10^{\circ}$

62.408

$250^{\circ} \mathrm{C}$

None

0.254 thick grafoil ${ }^{b}$

2.832

1.09

Tool steel

24.562

3.073

10

$250^{\circ} \mathrm{C}$

18.793

4.044

26.309

Low- $0.777 /$ high -0.823

Ampco 25 bronze

31.75

$30^{\circ} / 10^{\circ}$

$250^{\circ} \mathrm{C}$

Crown 8078 graphite sprayd

2.721

1.05

'Ampco Metal, Inc. (1745 South 38th St., Milwaukee, WI)

'GTA grade - Union Carbide Corp. (1300 Lakeside Ave., Cleveland, OH)

Fiske Brothers Refining Co. (129 Lockwood St., Newark, NJ)

${ }^{\circ}$ Crown Industrial Products Co. (P.O. Box 350, Hebron, IL) 


\section{PROCEDURE}

Both CVS cup open end wall thickness certification data and the corresponding blank thickness certification data were statistically analyzed. The certification data consisted of low and high values for both each fully fabricated cup and each as-ground (before final KCN cleaning) blank. The cup wall thickness measurements are made using a ball micrometer in numerous random locations, whereas the blank thickness measurements are made using standard (flat anvil) micrometers in at least seven locations.

Data were analyzed from the first 482 Cassini production cups, which included 30 Batch 2 (process prove-in) cups from D1 ingot material and 60 pilot production cups from CR3 ingot material. These cups were formed between September 1989 and September 1992. The data were analyzed separately from the more recent 636 Cassini parts that were formed after March 1993 through March 1994. Numerous changes were made in the CVS manufacturing processes between these two production periods. All Cassini production blanks were produced using the improved new process (drop cast, vacuum arc remelt- 63-mm-diam ingot, extrude, and roll), except for the 30 parts from the D1 ingot [new (had not been improved yet) process consisted of drop cast, vacuum arc remelt $51 \mathrm{~mm}$ diameter ingot, extrude and roll].

Also, data from 371 parts formed by EG\&G-Mound Applied Technologies, Inc. (EG\&G-MAT) for the Galileo/Ulysses missions were analyzed. The EG\&G-MAT-produced parts included 340 endof-production cups (Lots P041A, P042A, P045, P046, P047, P048, P049, and P050, which were formed in 1982 and 1983) and 31 cups (Lots I005, 1006, and I008, which were formed in 1985 and 1986) formed as follow-on work to evaluate the new process for blanks. Note: the 10 EG\&G-MAT cups from Lot 1005 were formed from old (drop cast and roll) process blanks as a control group for the new process blank evaluation. Table 1 compares the Energy Systems and EG\&G-MAT forming tooling parameters. 


\section{RESULTS AND DISCUSSION}

Table 2 summarizes some of the statistical analyses conducted on the blank and cup thickness data. The production data sets for both the Cassini and the Galileo/Ulysses missions consist of the final (after rework, if any) inspection results, whereas the EG\&G-MAT follow-on work inspection results were taken essentially in the as-formed condition.

Table 2. Statistical summary of blank and cup wall-thickness data [averages \pm single standard deviations $(\mathrm{mm})$ ]

\begin{tabular}{|c|c|c|c|}
\hline Material description & $\begin{array}{c}\text { Cup } \\
\text { quantity }\end{array}$ & $\begin{array}{l}\text { Wall thickness } \\
\text { low/high } \\
\text { (average } \pm \sigma \text { ) }\end{array}$ & $\begin{array}{c}\text { Cup } 8 \\
\text { high-low } \\
\text { (average } \pm \sigma \text { ) }\end{array}$ \\
\hline $\begin{array}{l}\text { Cassini production after March } 1993 \\
\text { Blanks }\end{array}$ & 636 & $0.658 \pm 0.008 / 0.666 \pm 0.007$ & \\
\hline Cups & & $0.667 \pm 0.013 / 0.709 \pm 0.011$ & $0.042 \pm 0.011$ \\
\hline $\begin{array}{l}\text { Cassini production before Sept. } 1992 \\
\text { Blanks }\end{array}$ & 482 & $0.650 \pm 0.011 / 0.658 \pm 0.009$ & \\
\hline Cups & & $0.649 \pm 0.017 / 0.707 \pm 0.016$ & $0.058 \pm 0.017$ \\
\hline $\begin{array}{l}\text { Galileo/Ulysses production } \\
\text { Blanks }\end{array}$ & 340 & $0.655 \pm 0.007 / 0.660 \pm 0.007$ & \\
\hline Cups & & $0.682 \pm 0.013 / 0.719 \pm 0.013$ & $0.037 \pm 0.013$ \\
\hline $\begin{array}{l}\text { EG\&G-MAT - old process (control) } \\
\text { Blanks }\end{array}$ & 10 & $0.659 \pm 0.007 / 0.665 \pm 0.005$ & \\
\hline Cups & & $0.692 \pm 0.016 / 0.754 \pm 0.017$ & $0.062 \pm 0.027$ \\
\hline $\begin{array}{l}\text { EG\&G-MAT - new process study } \\
\text { Blanks }\end{array}$ & 21 & $0.656 \pm 0.008 / 0.662 \pm 0.007$ & \\
\hline Cups & & $0.686 \pm 0.011 / 0.753 \pm 0.017$ & $0.067 \pm 0.013$ \\
\hline
\end{tabular}

Nearly $10 \%$ of the cups formed for Cassini before September 1992 were below the lower thickness limit of $0.63 \mathrm{~mm}$. These cups were formed using a first-form die diameter of $40.132 \mathrm{~mm}$ (1.580 in.). The data in Table 2 show that, on average, the Cassini blanks formed before September 1992 also were slightly thinner and more variable than any of the other blanks. In contrast, $<1 \%$ of the cups formed for Cassini after March 1993 were below the 0.63-mm thickness limit. The average cup low for these cups is $2.8 \%$ thicker than that of the earlier Cassini cups. The more recent Cassini cups were formed using a larger first-form die diameter of $40.178 \mathrm{~mm}(1.5818 \mathrm{in}$.). Table 2 shows that the average blank thicknesses for these cups were $1.2 \%$ greater and slightly less variable than those of the earlier Cassini blanks. The within-cup variability in wall thickness, $\delta$, is $28 \%$ lower (see Table 2) for the more recent Cassini production as well. Although the extent of rework required because of excessive cup wall thickness has not been quantified, it is known that only a small number of the more recently formed cups have exceeded the $0.73-\mathrm{mm}$ limit before rework, whereas a larger number of the earlier production cups had excessive wall thickness after forming. Note that the rework procedures for dye-penetrant indications and thick wall areas were improved to minimize the potential for excessive material removal. Although it is not clear what specific modification(s) [i.e., 
thicker blanks, larger first-form die diameter, improved rework procedures, or unidentified improvement(s) in forming based on additional experience] is most responsible for the changed wall thickness data, it is apparent that the forming process is significantly improved when compared with the earlier Cassini production.

All of the EG\&G-MAT cups were first-formed using a die diameter of $40.386 \mathrm{~mm}$ (1.590 in.). Table 1 shows that the stainless steel waster sheets and, thus, the blank assemblies used at EG\&GMAT were slightly thicker than those used at Energy Systems; therefore, the Energy Systems tooling dimensions had to be somewhat different to accomodate the typically $0.102-\mathrm{mm}(0.004$-in.) thinner blank assemblies. Nevertheless, the final punch/die clearance-to-blank assembly-thickness ratios at each facility were the same. These ratios, 1.09 for the first-form and 1.05 for the second-form operations, are consistent with conventional cupping and sizing draw operations, respectively.

Table 2 indicates that the Galileo/Ulysses production cups tended to be thicker with less withincup variation (lower 8 ) than the Cassini production cups. The data from the EG\&G-MAT old and new process study parts, which were inspected in the as-formed condition, indicate that a very large number of the cups formed by EG\&G-MAT required rework for thick walls. Reworking the thick wall areas would naturally lower the final within-cup variation and thus explain the low $\delta$ value for the Galileo/Ulysses production cups.

In some cases, the multiple effects of a forming campaign, material lot (ingot), and blank thicknesses could be separated for the Cassini production data. One case involved the use of $0.127-\mathrm{mm}$ - versus $0.254-\mathrm{mm}$-thick grafoil lubrication for the first-form operation. The data do not indicate a significant effect of grafoil thickness on cup wall thickness; however, the 0.254-mm-thick grafoil does offer more consistent lubrication. Based on this information 0.254-mm-thick grafoil is required for the first-form operation.

Another case involved the use of a blankholder during the first-form operation to minimize the formation of wrinkles. One forming campaign consisting of blanks from two different ingots was inadvertently first-formed without a blankholder. Comparing the data from this forming campaign with those from the other campaigns indicates that the blankholder has little or no effect on cup thinning at the open end; however, a blankholder does minimize the formation of wrinkles at the cup open end.

Additional analyses of the Cassini production data indicate that the expected relationship between blank thickness and cup thickness exists, but it tends to be rather weak for individual blanks/cups for a number of reasons. One reason is that the blank thicknesses are fairly tightly controlled by grinding (specification requirement of 0.63 to $0.68 \mathrm{~mm}$ ); therefore, effects from blank thickness variation are limited. Also, the low and high blank certification values can be located anywhere on a blank, so they do not necessarily involve the cup open end area. Another reason is that the cup certification inspection values are taken after all rework; thus, handwork in the open end area for dye penetrant indications or locally excessive wall thickness could alter the cup wall thickness data.

When the recent Cassini production data are grouped and averaged by each $0.01-\mathrm{mm}$ increment of low blank thickness $(0.62,0.63,0.64,0.65,0.66$, and $0.67 \mathrm{~mm})$, the expected relationships do exist as shown in Table 3. The cup wall thicknesses (lows and highs) strongly tend to increase as the low blank thicknesses increase, whereas the within-cup variations in wall thickness, 8 , tend to decrease as the low blank thicknesses increase. The correlation coefficients are significantly different from zero at the $95 \%$ confidence level. Also, the standard deviations for the cup lows and $\delta$ tend to decrease as the low blank thicknesses increase. The standard deviations for high cup-wall thicknesses are relatively constant; thus, they do not show a trend with low blank thickness. None of these correlation coefficients is statistically significant from zero at the $95 \%$ confidence level. 
Table 3. CVS cup wall thickness data for recent Cassini production by increment of low blank thickness

[arerages \pm single standard deviations (mm)]

\begin{tabular}{|c|c|c|c|c|c|c|c|}
\hline \multirow[b]{2}{*}{ Attribute } & \multicolumn{6}{|c|}{ Increment of low blank thickness (mm) } & \multirow{2}{*}{$\begin{array}{c}\text { Correlation } \\
\text { coefficient } \\
\text { (r-value) }\end{array}$} \\
\hline & 0.62 & 0.63 & 0.64 & 0.65 & 0.66 & 0.67 & \\
\hline Cup lows & $\begin{array}{c}0.640 \\
\pm \\
0.014\end{array}$ & $\begin{array}{c}0.640 \\
\pm \\
0.017\end{array}$ & $\begin{array}{c}0.654 \\
\pm \\
0.010\end{array}$ & $\begin{array}{c}0.663 \\
\pm \\
0.011\end{array}$ & $\begin{array}{c}0.668 \\
\pm \\
0.012\end{array}$ & $\begin{array}{c}0.676 \\
\pm \\
0.010\end{array}$ & $\begin{array}{l}+0.98^{\circ} \\
-0.67\end{array}$ \\
\hline Cup highs & $\begin{array}{c}0.691 \\
\pm \\
0.009\end{array}$ & $\begin{array}{c}0.687 \\
\pm \\
0.009\end{array}$ & $\begin{array}{c}0.696 \\
\pm \\
0.012\end{array}$ & $\begin{array}{c}0.704 \\
\pm \\
0.011\end{array}$ & $\begin{array}{c}0.710 \\
\pm \\
0.010\end{array}$ & $\begin{array}{c}0.717 \\
\pm \\
0.008\end{array}$ & $\begin{array}{c}+0.96^{\circ} \\
-0.11\end{array}$ \\
\hline $\begin{array}{l}\text { Cup } 8 \\
\text { (high-low) }\end{array}$ & $\begin{array}{c}0.051 \\
\pm \\
0.015 \\
\end{array}$ & $\begin{array}{c}0.047 \\
\pm \\
0.018\end{array}$ & $\begin{array}{c}0.042 \\
\pm \\
0.011 \\
\end{array}$ & $\begin{array}{c}0.041 \\
\pm \\
0.012 \\
\end{array}$ & $\begin{array}{c}0.042 \\
\pm \\
0.011 \\
\end{array}$ & $\begin{array}{c}0.042 \\
\pm \\
0.010 \\
\end{array}$ & $\begin{array}{l}-0.82^{2} \\
-0.79 \\
\end{array}$ \\
\hline
\end{tabular}

statistically significant. 


\section{CONCLUSION AND FUTURE WORK}

Statistical analyses of CVS cup open end wall thickness data show that the 636 recent Cassini production cups have well-controlled wall thicknesses.

Harasyn et al. ${ }^{3}$ showed that the DOP-26 iridium alloy can be deep drawn bare (without stainless steel waster sheets and tantalum barrier disks) in a single draw above $550^{\circ} \mathrm{C}$. This "bare" forming is being evaluated for use as the future CVS cup production forming process. Bare forming would not only eliminate up to 3 weeks of production processing time but also allow real-time feedback on the forming process. Concurrently, grinding of the open-end wall is being investigated to reduce further the variation in wall thickness. 


\section{REFERENCES}

1. M. A. Forrest, J. R. McDougal, and R. W. Saylor, General Purpose Heat Source (GPHS) Clad Vent Set (CVS) Formability Study, MLM-3395, pp. 5-6, November 3, 1986.

2. S. T. Mahmood and K. L. Murty, Characterization of Crystallographic Textures in Rolled and Recrystallized Iridium Sheets, final report submitted to Oak Ridge National Laboratory (attention: E. K. Ohriner), July 1990.

3. D. E. Harasyn, R. L. Heestand, and C. T. Liu, "Deep Drawing of Ir-0.3\% W Alloys," to be published in Materials Science and Engineering.

4. Metals Handbook, 9th ed., Vol. 14, "Forming and Forging," p. 581, ASM International, 1988. 


\section{DISTRIBUTION}

Department of Energy - Oak Ridge Operations

S. R. Martin, Jr.

R. L. Lahti

Department of Energy - Radioisotope Power Systems Division

W. J. Barnett

EG\&G-MAT, Inc.

W. R. Amos/E. W. Johnson (2)

Los Alamos National Laboratory

T. G. George

Oak Ridge National Laboratory

R. H. Cooper

J. F. King

E. K. Ohriner

M. M. Martin

J. P. Moore

\section{Oak Ridge Y-12 Plant}

H. W. Berry

V. L. Brasel

K. J. Helle

A. K. Lee/DOE-OSTI (2)

R. S. Leete

B. D. McElroy

M. W. Moyer

T. M. Mustaleski, Jr.

W. G. Northcutt/E. L. Bird

M. W. Sherrill

G. B. Ulrich (3)

A. T. Woods

R. C. Wright

Y-12 Central Files - RC 


$$
\checkmark
$$

$+$

$\bullet$

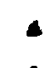

3

3 